\title{
Deep Neck Infections in Childhood
}

\section{Çocukluk Çağında Derin Boyun Enfeksiyonları}

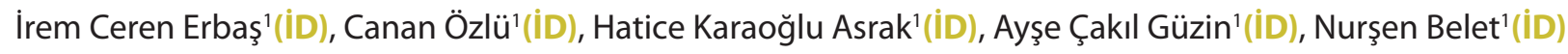 \\ ${ }^{1}$ Department of Pediatrics, Division of Pediatric Infectious Diseases, Dokuz Eylul University School of Medicine, Izmir, Turkey
}

Cite this article as: Erbaş iC, Özlü C, Karaoğlu Asrak H, Çakıl Güzin A, Belet N. Deep neck infections in childhood. J Pediatr Inf 2021;15(1):e38-e44.

\begin{abstract}
Objective: Deep neck infections (DNI) are infections that occur in potential cavities surrounded by the cervical fascia located on the neck. DNI is rarerly seen in childhood but carries a risk of serious morbidity and mortality. In treatment modalities, antibiotics can be used with or without surgery. In this study, we aimed to investigate children and adolescent cases with DNI and to compare patients who underwent surgery with those who did not.
\end{abstract}

Material and Methods: Data of the cases with DNI, who were diagnosed between 2014-2019 years, were collected from the medical records retrospectively.

Results: A total of 22 cases [12 girls (54.5\%)] diagnosed with DNI were included into the study. Median age of the patients was 2.66 years $(0.29$ 11 years). The most common complaint was neck swelling (86.4\%) and fever (68.2\%). On physical examination, limitation in neck movement (50\%) and cervical lymphadenopathy (40.9\%) were the most frequent findings. The majority of DNI were located in the parapharyngeal area. Surgical intervention was applied to $31.8 \%$ of the cases, with a median of six days after antibiotic treatment. All patients who underwent surgery had retropharyngeal abscess. The frequency of surgical intervention was found to be increased in cases with DNI diagnosed at a younger age or with a large size of abscess.

Conclusion: Patients with DNI should be followed closely for surgical intervention after antibiotic treatment is initiated. The risk of surgical intervention was increased especially in cases of young age, or who had retropharyngeal abscess or a large size of abscess. It was found that late application of surgical treatment did not increase complication, morbidity or mortality, but prolonged the hospital stay.

Keywords: Deep neck infection, children, retropharyngeal abscess, parapharyngeal abscess

\section{Öz}

Giriş: Derin boyun enfeksiyonları (DBE), boyunda yer alan servikal fasya ile çevrili potansiyel boşluklarda gelişen, çocuklarda nadir görülen fakat ciddi mortalite ve morbidite riski taşıyan enfeksiyonlardır. Tedavide yalnız antibiyotik tedavisi veya antibiyotik ile cerrahi tedavi birlikte uygulanır. Bu çalışmada DBE tanılı çocuk olgularda cerrahi uygulanan hastalar ile cerrahi uygulanmayan hastalar karşılaştırıldı ve cerrahi açısından risk faktörleri araştırıldı.

Gereç ve Yöntemler: Çalışmamızda 2014-2019 yılları arasında DBE tanılı olguların dosyaları geriye dönük olarak değerlendirildi.

Bulgular: Derin boyun enfeksiyonu tanılı 12'si kız (\%54.5) olmak üzere toplam 22 olgu çalışmaya dahil edildi. Hastaların ortanca yaşı 2.66 yıl (0.29-11 yıl) idi. En sık başvuru yakınması boyunda şişlik (\%86.4) ve ateşti (\%68.2). Fizik muayenede en sık boyunda hareket kısıtlılığı (\%50), servikal lenfadenopati (\%40.9) görüldü. DBE'li çocuklarda en sık yerleşim yeri parafaringeal alan idi. Cerrahi girişim, antibiyotik tedavisinden ortanca altı gün sonra, olguların \%31.8'ine uygulandı. Cerrahi girişim uygulanan tüm hastalar retrofaringeal apseye sahipti. Küçük yaşlarda veya apse boyutu büyük olan DBE tanılı olgularda cerrahi girişim sıklığı artmış olarak bulundu.

Sonuç: DBE tanılı olgular antibiyotik tedavisi başlandıktan sonra cerrahi girişim açısından yakın takip edilmelidir. Özellikle küçük yaş, retrofaringeal apse veya apse boyutu büyük olan olgularda cerrahi girişim riski artmıştır. Cerrahi tedavinin geç dönemde uygulanması komplikasyon, morbidite ve mortaliteyi arttırmamakta, ancak hastanede yatış süresini uzatmaktadır.

Anahtar Kelimeler: Derin boyun enfeksiyonu; çocuk; retrofaringeal apse; parafaringeal apse

Correspondence Address/Yazışma Adresi

İrem Ceren Erbaş

Dokuz Eylül Üniversitesi Tıp Fakültesi,

Çocuk Sağlığı ve Hastalıkları Anabilim Dalı,

Çocuk Enfeksiyon Hastalıkları Bilim Dalı,

İzmir-Türkiye

E-mail: iremceren_arslan@hotmail.com 


\section{Introduction}

Deep neck infections (DNI) are characterized by cellulite-phlegmon infections in the potential spaces of soft tissues surrounded by the cervical fascia of the neck and result in abscess formation. These are rarely seen infections in children with serious morbidity and mortality risk. DNI may cause life-threatening complications expanding to adjacent vital structures with late diagnosis and insufficient treatment (1). Its incidence is not fully known; however, recent studies have reported an increase in its prevalence $(2,3)$. This increase makes us consider that there are still problems related to diagnosis and treatment. Yet, there are studies reporting a decrease in incidence with wider use of antibiotics (4). When DNI is considered with history and physical examination, the abscess can be detected by neck computed tomography (CT). While early incision and drainage were recommended for treatment in the past, it has been shown in recent years that successful treatment is provided with intravenous antibiotics. In the pediatric age group, it has been demonstrated that there is no difference in complication rates between early surgical drainage and late surgery (5). Therefore, following patients with a 48-hour antibiotic treatment has been recommended before considering surgical drainage in recent years (5).

This study aimed to put forth the demographic characteristics, clinical findings, markers guiding diagnosis and effective treatment modalities in child cases diagnosed with DNI, and risk factors in terms of surgery were investigated comparing surgical and non-surgical patients.

\section{Materials and Methods}

In our study, the files of cases diagnosed with DNI between 2014 and 2019 were retrospectively reviewed. DNI diagnosis was made based on clinical symptoms, physical examination findings, neck contrast $C T$, magnetic resonance (MR) imagings results and growth in culture (6). A total of 22 cases, 12 girls and 10 boys aged under 18 years, were enrolled to the study. Cases with trauma, neck surgery or those developing DNI after foreign object and cases older than 18 years were excluded from the study.

Presenting complaints, physical examination findings, laboratory results, radiological findings, and surgical interventions were evaluated from patient files. During hospital admission, complete blood count, C-reactive protein (CRP), throat culture, blood culture, and blood biochemistry (serum transaminase, renal function tests and serum electrolytes) were tested in all cases. Abscess samples of all cases undergoing surgical procedure were added to the aerobe and anaerobe culture medium. Laboratory reference values for leucocyte count and CRP were $4.000-11.000 / \mathrm{mm}^{3}$ and $<5 \mathrm{mg} / \mathrm{L}$, respectively.
Contrast neck CT and MR were performed on patients considered to have DNI. Intravenous antibiotic treatment was initiated on patients admitted to hospital. Non-responsiveness to treatment was assessed when the symptoms did not regress and clinical recovery was not seen within the 24-48 hours of medical treatment. The patients were followed for complications, relapse and recurrence.

SPSS 24.0 statistical package was used for statistical analyses while evaluating the findings obtained. Descriptive statistics were given as number and percentage for categorical variables and as median value (min-max) for numerical variables. Pearson Chi-square test and Fisher's Exact test were used in the comparison of categorical variables, and Mann-Whitney $\mathrm{U}$ test was used in the comparison of parameters. Statistical significance was set at $p<0.05$.

\section{Results}

A total of 22 cases diagnosed with DNI, including 12 girls (54.5\%) were followed for 5 years. Median age of the patients was 2.66 years (0.29-11 years). The most common presenting complaints were swelling of the neck (86.4\%) and fever (68.2\%). Limitation of movement (50\%) and cervical lymphadenopathy $(40.9 \%)$ were seen most commonly on physical examination. Winter and fall months were the most frequent time of presentation. Leukocytosis was present in all but one case. Median leucocyte count was $21.200 / \mathrm{mm}^{3}(6.500-51.100 /$ $\left.\mathrm{mm}^{3}\right)$ and neutrophil counts was $13.650 / \mathrm{mm}^{3}(3.200-39.700 /$ $\left.\mathrm{mm}^{3}\right)$. CRP level was $11.8(1.5-38)$ times more the normal upper limit. Leucocyte and neutrophil counts and CRP elevation were found similar between surgical and non-surgical groups (Table 1). Streptococcus pyogenes growth was determined in the throat culture of one case (diagnosed with parapharyngeal abscess), and no growth was detected in the blood cultures of any case.

Contrast neck CT and MR were performed on 17 and 4 cases respectively. Neck CT of one case could not be reached since it was taken in another center. Radiological investigation revealed abscess in 16 (72.7\%) and suppurative lymphadenitis, phlegmon and inflammation in soft tissue in $6(27.3 \%)$ cases. DNI was detected most frequently in the parapharyngeal region $(54.6 \%, n=12)$. Retropharyngeal region, parapharyngeal and retropharyngeal region and parapharyngeal and peritonsillar region were involved concomitantly in five (22.7\%), three (13.7\%) and one (4.5\%) patient respectively. Peritonsillar abscess was present in only one case (4.5\%). All patients were started on antibiotic, analgesic-antipyretic and hydration upon admission. Ampicillin-sulbactam and clindamycin were administered to 11 patients (50\%), and ceftriaxone and clindamycin were started on 11 patients (50\%). Median length of hospital stay and intravenous treatment duration of the cases were 14 days (7-44 days). 
Erbaş et al.

Table 1. Comparison of the surgical and non-surgical patients' demographic characteristics, presenting symptoms, clinical findings, laboratory findings and infection location sites

\begin{tabular}{|c|c|c|c|}
\hline & Non-surgical Group ( $n=15)$ & Surgical Group $(n=7)$ & $\mathrm{p}$ \\
\hline Age, year (range) & $4.5(1-11)$ & $1(0.29-6.17)$ & 0.007 \\
\hline Sex, female (\%) & $8(53.3)$ & $4(57.1)$ & 0.867 \\
\hline Fever (\%) & $10(66.7)$ & $5(71.4)$ & 0.823 \\
\hline Neck pain (\%) & $2(13.3)$ & 0 & - \\
\hline Sore throat (\%) & $1(6.6)$ & 0 & - \\
\hline Limitation of neck movements (\%) & $8(53.3)$ & $3(42.9)$ & 0.647 \\
\hline Repression of teh uvula and tonsil (\%) & $2(13.3)$ & 0 & - \\
\hline Torticollis (\%) & $2(13.3)$ & 0 & - \\
\hline Trismus (\%) & $2(13.3)$ & 0 & - \\
\hline Leucocyte $\mathrm{mm}^{3} / \mathrm{L}$ & $19.000(6.500-43.200)$ & $21.300(15.000-51.100)$ & 0.378 \\
\hline Neutrophil mm³/L & $14.300(3.200-38.700)$ & $11.700(5.600-39.700)$ & 0.972 \\
\hline C-reactive protein elevation (times the normal upper limit) & $12.6(2-38)$ & $10(1.5-20)$ & 0.437 \\
\hline Parapharyngeal region (\%) & $12(54.5)$ & - & - \\
\hline Retropharyngeal region (\%) & - & $5(22.7)$ & - \\
\hline Peritonsillar region (\%) & $1(4.5)$ & - & - \\
\hline Parapharyngeal + retropharyngeal region (\%) & $1(4.5)$ & $2(9)$ & - \\
\hline Parapharyngeal + peritonsillar region (\%) & $1(4.5)$ & - & - \\
\hline
\end{tabular}

Fifteen cases recovered with only medical treatment (68.2\%). Surgical intervention was performed in five cases whose symptoms did not show any remission within 24-48 hours of medical treatment and swelling on the neck grew bigger and in two cases in whom abscesses were detected in multiple regions (31.8\%) (5 retropharyngeal abscess, 2 retropharyngeal-parapharyngeal abscess). Abscess culture was sent from all cases to whom surgical intervention was performed, and Staphylococcus aureus resistant to methicillin (MRSA) and susceptible to methicillin was detected in one patient each. The treatment of the case with MRSA was changed to vancomycin. Surgical intervention was performed on the patients median 6 days (2-18 days) after the start of intravenous antibiotic treatment. Antibiotic treatment of 17 cases following discharge was continued with oral amoxycillin-clavulanate, and treatment duration was median 10 days (7-20 days). Follow-up of the patients was uneventful with no complications, relapse or recurrence.

Presenting complaints and clinical findings of the surgical and non-surgical groups were similar ( $p>0.05$ ) (Table 1). The age of the cases receiving surgical intervention was significantly younger than those treated with only medical treat- ment $(p=0.007$ ) (Table 1). Length of hospital stay was found significantly longer in the surgical group compared to the non-surgical one $(p=0.005)$. Even though length of fever was longer in patients requiring surgical procedure, a statistical significance was not present $(p=0.095)$ (Table 1).

\section{Discussion}

The most common location was the parapharyngeal region in children with DNI in our study, and surgical intervention was performed on $31.8 \%$ of the patients. All patients undergoing surgical intervention had retropharyngeal abscess. Although time of surgical intervention was late, none of the patients had any complications or mortality. The age of the patients undergoing surgical intervention was younger, their abscess size was larger, and their length of hospital stay was longer.

DNI are rarely seen infections in children that could cause life-threatening complications. Its incidence is not fully known; however, recent studies have reported an increase in its prevalence $(2,3)$. Yet, there are studies reporting a decrease in incidence with wider use of antibiotics (4). They are referred to as peritonsillar, retropharyngeal and parapharyngeal ab- 
scess according to their locations in the anatomical spaces of the neck, and different results have been shown in the literature regarding their frequencies. While peritonsillar abscess is seen more frequently in adolescents and older children, retropharyngeal abscess is more common in children aged younger than 5 years. Parapharyngeal abscesses can be seen at any age (7). In a study investigating 117 children diagnosed with DNI, peritonsillar infection (49\%) followed by retropharyngeal infection (22\%) has been reported most commonly, and parapharyngeal abscess has been reported to be rare in children (8). Yang et al. (9) have reported that 44 (34\%) of the 130 cases diagnosed with DNI were under the age of 18 and have confirmed parapharyngeal abscess $(40.9 \%)$ the most. Novis et al. (10) determined peritonsillar abscess the most (69\%) in 1483 pediatric cases between 2000 and 2009 and stated that increase in patient numbers was seen as of 2000. In a study from our country (11), parapharyngeal abscess (75\%) has been reported the most. In our study, parapharyngeal abscess (54.6\%) was detected the most, and wide distribution of the age in our study was considered to have caused the difference from other studies in the literature. It has been reported in the USA and Europe that DNI prevalence increases in winter and fall months $(12,13)$. Similarly, the most frequent hospital presentation was in winter and fall months in our study.

History and physical examination findings are quite important in DNI diagnosis. It leads to symptoms like swelling and pain in the neck, limitation of neck movements, fever, difficulty to swallow and trismus. Limitation in neck movements is particularly important in differentiating it from cervical lymphadenopathy, which is open of the most common causes of swelling of the neck $(14,15)$. Côrte et al. (4) have confirmed the most common symptoms in their study including 156 children with DNI as fever (63.9\%), odynophagia (50.6\%), swelling in the throat (46.1\%) and limitation in neck movements (35\%). In a study from our country, the most common symptoms have been reported as fever (83\%) and swelling of the neck (67\%) (11). In our study, similar to the literature data, the most common symptoms were found as swelling of the neck (86.4\%), fever (68.2\%) and limitation of neck movement $(31.8 \%)$.

DNI is mostly polymicrobial. The most commonly isolated bacteria are Streptococcus pyogenes, S. aureus and Haemophilus influenzae and anaerobic bacteria (Bacteroides spp., Provetella spp., Fusobacterium spp., Peptostreptococcus spp.). Therefore, the specimen taken should be added into both aerobe and anaerobe culture media $(16,17)$. In the literature, S. pyogenes, S. aureus and anaerobe bacteria have been reported as the most frequently growing agents in abscess cultures $(18,19)$. In a study conducted in 2017 (4), abscess culture was sent from
87 pediatric cases, and growth was detected in 40 of them (45.9\%). The most frequently isolated pathogen was reported as Streptococcus pyogenes. In our study, methicillin susceptible S. aureus was grown in one case and MRSA in another out of the abscess cultures sent from seven cases undergoing surgical intervention. Polymicrobial and anaerobe microorganisms were not confirmed. It was considered that antibiotic use prior to hospital admission affected the culture results.

Neck CT has an important role in DNI diagnosis. Neck CT evaluated the size of the abscess, its location, its extension to adjacent spaces, and its relation with vascular structures; however, CT findings may not always differentiate cellulite and inflammatory edema. It has been reported in the literature that $10-25 \%$ of the cases diagnosed with abscess through CT are not surgically proven abscess. Therefore, the gold standard in surgery is demonstrating pus presence with surgical exploration and the growth of the agent in culture (20-22). Apart from $C T, M R$ can also be used as imaging modality, and it is argued that MR may replace CT in the near future. While it is an advantage that MR does not have a radiation risk and defines the soft tissue better, its disadvantages include its cost, longer duration and that it cannot be used in emergencies in younger children as they need sedation (4). Côrte et al. (4) have surgically confirmed DNI diagnosis in $63 \%$ of the cases $(n=87)$ who were radiologically diagnosed with $\mathrm{DBl}$; however, while $\mathrm{CT}$ has detected abscess in $17.4 \%$ of the cases, it has not been confirmed surgically. In our study, imagings findings revealed abscess formation in 16 cases and lymphadenitis, phlegmon and inflammation in soft tissue in 6 cases. Purulent content was determined and abscess diagnosis was confirmed in 7 cases detected having abscess by imaging modalities and having undergone surgical intervention. The reason for obtaining compatible imagings and surgical findings in these patients may be related to late surgical intervention (median 6 days).

While early incision and drainage were recommended for treatment in the past, treatment has been shown to be successful with intravenous antibiotics in recent studies (5). Therefore, following patients with a 24-48-hour antibiotic treatment is recommended in cases that have an abscess localized in a single place and no respiratory problems prior to surgical drainage (23-26). Systemic antibiotic treatment must be started as soon as DNI diagnosis is made. There is no consensus on the empirical antibiotic choice in treatment, what to do in case treatment fails and how to prevent complications. Due to the fact that $\beta$-lactamase-producing organisms and $S$. aureus and polymicrobial infections are common, single penicillin or ampicillin is insufficient. Empirical treatment should be started against possible agents (S. pyogenes, S. aureus, anaerobes), and treatment should be adapted according to cul- 
ture results. Appropriate empirical antibiotic regimens include second or third generation cephalosporin and clindamycin or metronidazole, amoxycillin-clavulanate, ampicillin-sulbactam and piperacillin-tazobactam $(8,27)$. Clindamycin or vancomycin should be used according to the local resistance rates of $S$. aureus and the clinical status of the patient (28). Similar to the literature, empirical third generation cephalosporin or ampicillin-sulbactam and clindamycin treatment were started in all cases in our study. The treatment was changed to vancomycin in one patient since MRSA grew in culture.

Surgical intervention has been reported in the literature at a rate of $25-87 \%(4,11)$. In our study, surgical intervention was required in $31.8 \%(n=7)$ of the cases, compatible with the literature. There are various rates when the frequency of surgical intervention is considered according to the location of DNI $(4,11)$. It has been shown in a study that surgical intervention was required in all retropharyngeal abscesses (4). Kim et al. (29) have reported that the need for surgical treatment increased in cases older than 7.5 years with peritonsillar abscesses. In our study, primary abscess site was the retropharyngeal region in cases undergoing surgical intervention, and surgical intervention was performed in all abscesses of this region except for one patient. Two cases with peritonsillar abscesses aged 4 and 7 were seen to have recovered with only medical treatment.

In the pediatric age group, it has been demonstrated that there is no difference in complication rates between early surgical drainage and late surgery (5). In a prospective study by Cramer et al. (30) including 347 adult and 665 pediatric cases diagnosed with $\mathrm{DNI}$, the authors have researched the relation between late surgery and mortality and morbidity risk and concluded that mortality and morbidity rises in the adult groups but not in the pediatric group. The reason for this condition has been considered to be due to different reasons of abscess formation in adults and children. While it is argued in adults that abscess formation is due to trauma or direct spread of the infection from adjacent structures, it is considered that suppurative changes in lymph nodes that occur after infections of the sinuses, adenoids, tonsils or the tympanum in children. The clinical importance of this difference is that there is a risk of fast spread of adult infections and that pediatric infections are limited to the lymph node and its spread is prevented in the early phase (30). In our study, it was seen that surgical intervention had been performed median 6 days after medical treatment. The reason for this condition was that our center is a reference center for children with DNI and that the seven cases having undergone surgical intervention had received intravenous treatment in another center and then referred to us in the late period for surgical drainage. The cas- es were operated on within the first 48 hours of being admitted to our center. Surgical intervention was performed late in our cases independent of our doing, and this lateness did not cause any complication, morbidity or mortality in any case.

In the literature, it has been argued if abscess size on CT is a guide in terms of medical and surgical treatment, and its relation with high complication risk has been discussed, but no consensus has been reached. Côrte et al. (4) have reported that $21(13 \%)$ of the 156 children diagnosed with DNI recovered only with medical treatment, most of these cases were under 10 years of age and had abscesses sized smaller than 2 $\mathrm{cm}$. Cheng et al. (31) have shown in 178 pediatric cases diagnosed with DNI that high leucocyte count, abscess diameter larger than $2.2 \mathrm{~cm}$ and young age $(<4.25$ years) are associated with increased surgical intervention. Bolton et al. (32) have reported that more attention should be paid in terms of complication in children aged younger than 2 years with high leucocyte count and DNI diagnosis. Wong et al. (33) have demonstrated in 54 pediatric cases that surgery frequency is higher in younger aged children with an abscess smaller then $2 \mathrm{~cm}$ compared to older children. Surgical treatment has been reported to be required in $85 \%$ of children with abscess larger than $2.5 \mathrm{~cm}$ (33). In our study, while median abscess size was $2 \mathrm{~cm}$ and age was 4.5 years in cases recovering with only medical treatment, abscess size of those in whom surgical intervention was performed was $4 \mathrm{~cm}$ and they all aged 1 year. It was seen, parallel to the literature, that surgical intervention requirement increased in cases aged younger with abscesses sized larger than $2 \mathrm{~cm}$.

Treatment duration in DNI diagnosis changes according to clinical response. It has been found in a study (4) that length of hospital stay in the adolescent age group was median 3 days (2-12 days) and median 6 days (2-27 days) in the younger age group. Cramer et al. (30) have found that length of hospital stay was longer in cases undergoing surgical intervention in the pediatric age group compared to those without surgery. In another study, a significant difference was not shown between medical treatment and surgical drainage in terms of length of hospital stay (33). In our study, length of hospital stay and intravenous treatment duration was median 14 days, and this duration was found significantly higher in the group undergoing surgery. According to the literature, it was considered that the longer length of hospital stay was due to late surgical intervention.

Despite being rare, DNI can cause life-threatening complications spreading to adjacent spaces. It is aspired opening to the trachea, and it may cause mediastinitis, empyema, aspiration pneumonia, pleural empyema, pericarditis, airway obstruction, internal jugular vein thrombosis, carotid artery 
aneurism, erosion and rupture, and sepsis $(6,12,28)$. Mortality rate and relapse and recurrence rates have been reported as $1-8.7 \%$ and $5-10 \%$ respectively $(12,13)$. Even though surgical intervention was performed late in our study, no complication, morbidity, mortality, relapse, and recurrence were observed.

\section{Conclusion}

The most common location in children with DNI in our study was the parapharyngeal region, and $31.8 \%$ of our cases underwent surgical intervention. All patients receiving surgical intervention had retropharyngeal abscess, and frequency of surgical intervention was found higher in younger children and in those with larger sized abscesses. It was detected that patients with retropharyngeal abscess should be closely followed for surgical intervention after the start of antibiotic treatment and that surgical intervention performed in the late period did not increase complications, morbidity and mortality but prolonged the length of hospital stay.

Ethics Committe Approval: The approval for this study was obtained from Dokuz Eylül University Non-invasive Research Ethics Committee (Decision no: 2020/21-25 Date: 14.09.2020).

Informed Consent: Patient consent was obtained.

Peer-review: Externally peer-reviewed.

Author Contributions: Concept-iCE, NB; Design-iCE, NB; Supervision - NB; Resource - ICE; Data Collection and/or Processing - ICE, CÖ, HAK, AÇG; Analysis and/or Interpretation - ICE, NB; Literature Search - ICE, CÖ, HAK, AÇG; Writing - ICE; Critical Review - All of authors.

Conflict of Interest: Authors declared no conflict of interest.

Financial Disclosure: The authors declared that this study has received no financial support.

\section{References}

1. Goldstein NA, Hammerschlag MR. Peritonsillar, retropharyngeal, and parapharyngeal abscesses. In: Feigin RD, Cherry JD, Harrison GJ, Kaplan $S L$, Steinbach WJ, Hotez BJ, editors. Textbook of Pediatric Infectious Disease, $8^{\text {th }}$ ed. Philadelphia, PA: Elsevier, 2019. p: 117-23. [CrossRef]

2. Cabrera CE, Deutsch ES, Eppes S, Lawless S, Cook S, O'Reilly RC, et al. Increased incidence of head and neck abscesses in children. Otolaryngol Head Neck Surg 2007;136(2):176-81.[CrossRef]

3. Kirse DJ, Roberson DW. Surgical management of retropharyngeal space infections in children. Laryngoscope 2001;111:1413-22.[CrossRef]

4. Côrte FC, Firmino-Machado J, Moura CP, Spratley J, Santos M. Acute pediatric neck infections: Outcomes in a seven-year series. Int J Pediatr Otorhinolaryngol 2017;99:128-134. [CrossRef]

5. Tansey JB, Hamblin J, Mamidala M, Thompson J, Mclevy J, Wood J, Sheyn A. Dexamethasone use in the treatment of pediatric deep neck space infections. Ann Otol Rhinol Laryngol 2020;129(4):376-9. [CrossRef]

6. Lawrence $R$, Bateman $N$. Controversies in the management of deep neck space infection in children: an evidence-based review. Clin Otolaryngol 2017;42(1):156-63. [CrossRef]
7. Tebruegge M, Curtis N. Infections of the Upper and Middle Airways. In: Sarah S. Long SS, Prober CG, Fischer M, editors. Principles and Practice of Pediatric Infectious Diseases, $5^{\text {th }}$ ed. Philadelphia, PA: Elsevier, 2018. p: 1073-119. [CrossRef]

8. Ungkanont K, Yellon RF, Weissman JL. Head and neck space infections in infants and children. Otolaryngol Head Neck Surg 1995;112:375-82. [CrossRef]

9. Yang $W, H u L$, Wang $Z$, Nie G, Li X, Lin D, et al. Deep neck infection: A review of 130 cases in Southern China. Medicine (Baltimore) 2015;94:e994. [CrossRef]

10. Novis SJ, Pritchett CV, Thorne MC, Sun GH. Pediatric deep space neck infections in U.S. children, 2000-2009. Int J Pediatr Otorhinolaryngol 2014;78(5):832-6. [CrossRef]

11. Belet $N$, Tapısız A, Uçar Y, Çiftçi E, Fitöz S, Ince E, et al. Deep neck ınfections in children. J Pediatr Inf 2007;1:58-62. [CrossRef]

12. Singla A, Singh S, Goraya JS, Radhika S, Sharma M. The natural course of nonsuppurative calmette-guérin bacillus lymphadenitis. Pediatr Infect Dis J 2002;21:446. [CrossRef]

13. Scagni P, Peisino MG, Bianchi M, Morello M, Sardi N, Linari A, et al. Kikuchi-Fujimoto disease is a rare cause of lymphadenopathy and fever of unknown origin in children: report of two cases and review of the literature. J Pediatr Hematol Oncol 2005;27:337. [CrossRef]

14. Larawin V, Naipao J, Dubey SP. Head and neck space infections. Otolaryngol Head Neck Surg 2006;135:889-93. [CrossRef]

15. Wang LF, Kuo W-R, Tsai SH, Huang KJ. Characterizations of life-threatening deep cervical space infections: A review of one hundred ninety-six cases. Am J Otolaryngol 2003;24:111-7. [CrossRef]

16. Brook I. Microbiology and management of peritonsillar, retropharyngeal, and parapharyngeal abscesses. J Oral Maxillofac Surg 2004;62:1545-50. [CrossRef]

17. Brook I, Frazier EH, Thompson DH. Aerobic and anaerobic microbiology of peritonsillar abscess. Laryngoscope 1991;101:289-92. [CrossRef]

18. Cabrera CE, Deutsch ES, Eppes S, Lawless S, Cook S, O'Reilly RC, et al. Increased incidence of head and neck abscesses in children. Otolaryngol Head Neck Surg 2007;136:176-81. [CrossRef]

19. Thorell AE. Cervical Lymphadenitis and Neck Infections in Principles and Practice of Pediatric Infectious Diseases, Fifth Edition. In: Long SS, Prober CG, Fischer M. eds. Philadelphia. 2018; p:780-826. [CrossRef]

20. Flanary VA, Conley SF. Pediatric deep space neck infections: the Medical College of Wisconsin experience. Int J Pediatr Otorhinolaryngol 1997;38:263-71. [CrossRef]

21. Vural Ç, Güngör A, Comerci S. Accuracy of computerized tomography in deep neck infection in the pediatric population. Am J Otolaryngol 2003;24:143-8. [CrossRef]

22. Sichel J-Y, Gomori JM, Saah D, Elidan J. Parapharyngeal abscess in children: the role of CT for diagnosis and treatment. Inter J Pediatr Otorhinolaryngol 1996;35:213-22. [CrossRef]

23. Dorfman RF, Berry GJ. Kikuchi's histiocytic necrotizing lymphadenitis: an analysis of 108 cases with emphasis on differential diagnosis. Semin Diagn Pathol 1988;5(4):329-45. [CrossRef]

24. Bowen FJ, Bright A, Rode JW, Brewster D. Donovanosis causing cervical lymphadenopathy in a five-month-old boy. Pediatr Infect Dis J 2000;19:167-9. [CrossRef]

25. Chuang CH, Yan DC, Chiu CH, Huang YC, Lin PY, Chen CJ, et al. Clinical and laboratory manifestations of Kikuchi's disease in children and differences between patients with and with out prolonged fever. Pediatr Infect Dis J 2005;24(6):551-4. [CrossRef]

26. Serour F, Gorenstein A, Somekh E. Needle aspiration for suppurative cervical lymphadenitis. Clin Pediatr (Phila) 2002;41(7):471-4. [CrossRef] 
Erbaş et al.

27. Colville A. Retrospective review of culture-positive mycobacterial lymphadenitis cases in children in Nottingham, 1979-1990. Eur J Clin Microbiol Infect Dis 1993;12(3):192-5. [CrossRef]

28. Kanegaye JT, Van Cott E, Tremoulet AH. Lymph-node first presentation of Kawasaki disease compared with bacterial cervical adenitis and typical Kawasaki disease. J Pediatr 2013;162:1259. [CrossRef]

29. Kim DK, Lee JW, Na YS, Kim MJ, Lee JH, Park CH. Clinical factor for successful nonsurgical treatment of pediatric peritonsillar abscess. Laryngoscope 2015;125:2608-11. [CrossRef]

30. Cramer JD, Purkey MR, Smith SS, Schroeder JW Jr. The Impact of delayed surgical drainage of deep neck abscesses in adult and pediatric populations. Laryngoscope 2016;126(8):1753-60. [CrossRef]
31. Cheng J, Elden L. Children with deep space neck infections: our experience with 178 children. Otolaryngol Head Neck Surg 2013;148:1037-42. [CrossRef]

32. Bolton $M$, Wang W, Hahn A, Ramilo O, Mejias A, Jaggi P. Predictors for successful treatment of pediatric deep neck infections using antimicrobials alone. Pediatr Infect Dis J 2013;32:1034-6. [CrossRef]

33. Wong DK, Brown C, Mills N, Spielmann P, Neeff M. To drain or not to drain - management of pediatric deep neck abscesses: a case-control study. Int J Pediatr Otorhinolaryngol 2012;76:1810-3. [CrossRef] 